\title{
Optimasi Protokol Routing ZRP Menggunakan PA-SHORT untuk Mengurangi Jumlah Hop Pada Suatu Rute di Jaringan Manet
}

\author{
(ZRP Routing Protocol Optimization Using PA-SHORT to Reduce the Number of \\ Hop on a Route on the MANET Network)
}

\author{
Laeli Oktami, Andy Hidayat Jatmika, Nadiyasari Agitha* \\ Program Studi Teknik Informatika, Fakultas Teknik, Universitas Mataram \\ Jl. Majapahit 62, Mataram, Lombok NTB, INDONESIA \\ Email: laelioktami19@gmail.com, [andy, nadiya]@unram.ac.id
}

*Penulis korespondensi

\begin{abstract}
MANET is a dynamic node's network that can move anywhere when a route has been found that broken links often occur due to high mobility. ZRP is a protocol for finding routes in a hybrid. The working principle of ZRP is that each node will create a zone so that it can create a multihop path if the length of the number of hops causes a high delay effect and decreases the value of throughput. To overcome this problem, we need an algorithm that can eliminate a number of hops by finding a shortcut. The suitable algorithm to use is the PA-SHORT algorithm which is applied to the $\mathrm{ZRP}$ routing protocol framework to optimize the main route to eliminate the number of hops. In this study, the authors conducted 5 experiments with results that showed an increase in throughput in the $1000 \times 1000 \mathrm{~m} 2$ area of $52,081 \%$ for nodes 20 , on average E2D contained a $0.737 \%$ decrease for nodes 20 in a $500 \times 500 \mathrm{~m} 2$ area, and PDR increased by 64,931\% for nodes 20 in an area of $500 \times 500$ $\mathrm{m} 2$. in a suitable area of $1000 \times 1000 \mathrm{~m} 2$ the results of routing overhead contain a decrease of $36.815 \%$ for nodes 20 .
\end{abstract}

Key words: ZRP, PASHORT-ZRP, Path Aware SHORT, MANET, NS-2.

\section{PENDAhUluan}

Mobile ad hoc network (MANET) merupakan jaringan yang terdiri dari beberapa simpul yang dapat disesuaikan dan dapat berkumpul secara spontan kemudian berkomunikasi dengan cara menggunakan antarmuka nirkabel (wireless interface) tanpa memerlukan infrastruktur yang bersifat tetap dengan topologi yang dinamis dan setiap simpul memiliki kedudukan yang sama[1]. Trend Isu penelitian di bidang MANET yang paling banyak dilakukan dari tahun 1998 hingga saat ini adalah routing. Routing adalah langkah pada saat melakukan pengiriman data atau informasi dengan meneruskan paket daya yang dikirim dari jaringan satu ke jaringan lainnya[2]. Dalam proses routing dibutuhkan protokol yang mencari rute dari sumber ke tujuan. Sifat protokol routing ada tiga yaitu, reaktif digunakan hanya saat rute dibutuhkan, proaktif selalu memperbaharui informasi routing dalam jaringan, dan hybrid merupakan gabungan dari reaktif dan proaktif.

Simpul dalam MANET dapat berpindah kemana saja, sehingga topologi jaringan mengalami perubahan secara signifikan tanpa dapat diprediksi, hal ini dapat mempengaruhi kinerja protokol routing[3]. Permasalahan yang sering timbul pada jaringan ini adalah bagaimana mengoptimalkan jumlah hop dalam proses pencarian rute. Beberapa penelitian yang pernah dilakukan unuk mengurangi jumlah hop antara lain yaitu, penelitian protokol routing AODV dan DSR dengan Algoritma Path Aware Short yang dilakukan oleh [4], [5], [6], dan [7]. Dari penelitian yang telah disebutkan terdapat beberapa jenis protokol routing yang digunakan yaitu protokol routing yang bersifat reaktif. Sehingga perlu dilakukan penelitian protokol routing dengan sifat lainnya menggunakan algoritma PA-SHORT

Pada penelitian ini digunakan protokol routing Zone Routing Protocol (ZRP) yang bersifat hybrid. Prinsip kerja ZRP adalah setiap simpul akan membuat sebuah zona. Besaran setiap zona tergantung pada radius yang didefinsikan pada jumlah hop (lompatan) pada setiap simpulnya. Untuk simpul-simpul yang berada di dalam zona, rute menuju suatu simpul akan langsung ditemukan (sifat proaktif), namun ketika simpul tujuan berada di luar zona, maka akan dilakukan prosedur penemuan rute (sifat reaktif). Dalam ZRP, pengetahuan yang dimiliki oleh topologi lokal dapat digunakan untuk pemeliharaan rute. Letak kegagalan link dan segmen rute sub-optimal dalam satu zona dapat diatasi. Paket yang masuk dapat diarahkan ke link lainnnya di sekitar link yang rusak melalui jalur multi-hop aktif.

Jika semakin panjang jumlah hop pada suatu rute, maka akan menyebabkan delay yang tinggi dan menurunnya throughput. Simpul intermediate dengan mobilitas tinggi dapat terjadi pada rute yang dipilih. Hal ini menyebabkan topologi mengalami perubahan bentuk. Perubahan topologi ini dapat dimanfaatkan dengan mengurangi jumlah hop sebelum terjadi kerusakan rute, 
sehingga diharapkan mampu meningkatkan throughput dan delay. Salah satu metode untuk mengurangi jumlah hop adalah algoritma Path aware Short.

Path Aware Short (PA-SHORT) adalah suatu mekanisme pengoptimalan panjang rute yang memiliki keuntungan peningkatan kinerja dalam hal bandwidth dan latency. Tujuan dari algoritma ini adalah mencoba untuk mempersingkat panjang jalur bila memungkinkan. Rute yang lebih pendek tidak hanya mengurangi latency, tetapi juga meningkatkan throughput [4].

Pengoptimalan rute dengan PA-SHORT mencoba memendekkan rute utama ketika terjadi mobilitas simpul yang mengakibatkan perubahan bentuk rute untuk kecepatan pengiriman paket data. Algoritma PA-SHORT mencoba melakukan koneksi dengan simpul yang masih dalam jangkauan simpul intermediate dengan membentuk link untuk pengoptimalan. Protokol routing yang telah diterapkan algoritma PA-SHORT diperuntukkan dalam menemukan rute dengan mengurangi jumlah hop, sehingga efisiensi rute sangat penting dalam memfasilitasi komunikasi antar jaringan. Proses pengiriman paket data dalam jaringan komunikasi berlangsung dengan cepat adalah tujuan dari efisiensi rute tersebut.

Pada penelitian ini dilakukan modifikasi pada kerangka protokol routing ZRP untuk mengoptimalkan rute utama dengan cara mengurangi jumlah hop menggunakan algoritma PA-SHORT. Kinerja protokol routing yang diukur adalah jumlah throughput, rerata end to end delay, Rasio Pengiriman Paket (PDR), dan routing overhead pada simulasi percobaan yang berbeda dengan memvariasikan beberapa parameter simulasi. Simulasi protokol routing akan dibuat menggunakan tools Network Simulator 2 (NS2) versi 2.35, sedangkan untuk analisis terhadap parameter uji menggunakan AWK Script yang mempunyai kegunaan untuk mem-parsing atau mengurai file .tr yang terdapat pada NS2. Hasil dari penelitian ini diharapkan, bahwa Algoritma PA-SHORT yang diterapkan dalam protokol routing ZRP mampu mengoptimalkan performansi jaringan dalam mempersingkat rute dengan mengurangi jumah hop.

\section{Penelitian TeRKait}

Adapun penelitian terkait yang digunakan sebagai acuan dalam melakukan penelitian yaitu sebagai berikut:

a. Penelitian dengan membandingkan runutan cara kerja dari protokol routing AODV dan ZRP dalam mengetahui kelebihan dan kekurangan dari masingmasing protokol pada saat diterapkan di jaringan MANET. Langkah simulasi yang digunakan untuk menganalisis QoS jaringan pada protokol routing AODV dan ZRP adalah dengan meproyeksikan pola posisi yang sama antara protokol routing AODV dan ZRP. Parameter uji dalam penelitian ini menggunakan Jitter, Packet delivery ratio, Delay, dan Throughput dengan luas area $1000 \mathrm{~m} \times 1000 \mathrm{~m}$. Nilai hasil yang diberikan oleh throughput yang lebih memadai dengan menggunakan protokol ZRP. ZRP dapat menganalisis lebih awal simpul tujuan dalam pengiriman paket lebih baik. Nilai rerata throughput pada ZRP adalah $963.34 \mathrm{~Kb}$ sedangkan AODV yang hanya $920.04 \mathrm{~Kb}$. Delay pada routing protocol AODV lebih sedikit dibandingkan dengan ZRP. AODV menghasilkan nilai rerata sebesar 0.3134 dibandingkan dengan ZRP yang lebih besar yaitu 0.3891 . Kesimpulan dari penggunaan Jitter pada protocol adalah routing protokol ZRP bernilai lebih tinggi dibandingkan dengan AODV, dikarenakan protocol AODV mengirimkan paket dengan simpul tujuan yang paling dekat. Dengan nilai jitter dari AODV adalah 0.9026. [8].

b. Penelitian ini melakukan analisis protokol routing ZRP pada MANET dengan cara pendekatan simulasi memakai Network Simulator 2 (NS-2). Parameter uji yang digunakan yaitu Throughput, Delay, dan PDR dengan jumlah simpul 10, 20, 50, dan 100. Hasil dari simulasi yang dilakukan diperoleh protokol routing ZRP memiliki throughput rerata yang dihasilkan sebesar 402,115 Kbps. Nilai throughput yang diamati semakin menurun disesuaikan pada pertambahan jumlah simpul dengan nilai tertinggi sebesar 727,081 Kbps pada simulasi pertama dengan simpul berjumlah 10 dan paling rendah bernilai 34,5702 Kbps pada simulasi keempat dengan jumlah simpul 100. Sedangkan delay memiliki rata-rata sebesar 1,083842 s. Nilai delay ZRP yang diamati semakin meningkat dari $0,606597 \mathrm{~s}$ pada percobaan simulasi pertama dan pada percobaan simulasi keempat mencapai 2,00939 s. Protokol routing ZRP memiliki nilai PDR rata-rata sebesar 76,114 \%. Perbedaan nilai parameter performansi protokol routing yang jauh berbeda tidak terjadi pada hasil perhitungan nilai PDR, dimana penurunan rerata yang terjadi sebesar $5.8 \%[9]$.

c. Penelitian untuk mengimplementasikan metode yaitu, Optimalisasi routing dengan menggunakan metrik yang berbeda seperti panjang lintasan dan pemakaian energi di sepanjang jalur didefinisikan. Kemudian diusulkan sebuah kerangka kerja Self-Healing and Optimizing Routing Techniques (SHORT) untuk MANET. Saat menggunakan SHORT, semua simpul tetangga memantau rute dan mencoba mengoptimalkannya bila ada jalur yang lebih baik. Pada penelitian ini, algoritma SHORT diterapkan untuk protokol routing AODV dan DSR. Algortima SHORT meningkatkan optimalisasi routing dengan memonitor jalur routing secara terus menerus dan secara bertahap mengarahkan rute untuk lebih optimal. Hasil simulasi menunjukkan bahwa tingkat pengiriman yang lebih tinggi dan network lifetime yang lebih panjang. Tingkat pengiriman naik sekitar $8 \%$ pada AODV-SHORT dan $6 \%$ pada DSR-SHORT, serta overhead mengalami penurunan sekitar $10 \%$ [4].

d. Penelitian selanjutnya membahas analisis perbandingan perhitungan kerja protokol routing TORA dan TORA dengan menggunakan algoritma SHORT. Algoritma ini meningkatkan optimalisasi routing secara bertahap memperpendek rute. Hasil 
simulasi menunjukkan bahwa throughput yang lebih tinggi meningkat hingga $3-50 \%$, end-to-end delay yang lebih rendah hingga $50 \%$, delay mengalami penurunan sebesar $50 \%$, penurunan packet loss bervariasi dari $12-57 \%$, perbaikan energi sekitar $43 \%$, dan life time jaringan yang lebih tinggi. TORA yang dimodifikasi mengungguli protokol routing TORA dalam hal throughput, packet loss, end-to-end delay, dan energi [5].

e. Efisiensi rute dengan metode yang sama dilakukan untuk pencarian rute pada protokol DSR pada penelitian ini yaitu pencapaian maksimal pencarian rute diantara simpul yang tidak membebani link, karena jika terjadi kegagalan link maka akan dilakukan route discovery ulang. Perhitungan optimasi rute menggunakan fungsi obyektif digunakan untuk mencapai rute mendapatkan nilai maksimal dengan parameter waktu tempuh yang paling sedikit. Untuk mencapai link - link yang maksimal, maka digunakan Algoritma PA-SHORT dengan mengetahui bahwa link yang menjadi rutenya dalam kondisi sesuai dengan harapan. Nilai parameter yang digunakan AVG, NRL, dan PDR. Penelitian menggambarkan bahwa ujicoba simulasi I nilai maksimal AVG untuk 50 simpul $0.002 \mathrm{~m} / \mathrm{s}$ dan 100 simpul $0.0051 \mathrm{~m} / \mathrm{s}$. Nilai maksimal NRL untuk 50 simpul 0.026 dan 100 simpul 0.0136 . Nilai maksimal PDR untuk 50 simpul $78.5801 \%$ dan 100 simpul $81.7333 \%$. Sedangkan hasil ujcoba simulasi II nilai maksimal AVG untuk 50 simpul $0.0004 \mathrm{~m} / \mathrm{s}$ dan 100 simpul $0.0007 \mathrm{~m} / \mathrm{s}$. Nilai maksimal NRL untuk 50 simpul 0.0112 dan 100 simpul 0.0058 . Nilai optimum PDR untuk 50 simpul $85.6523 \%$. dan 100 simpul 98.9327\% [6].

f. Penelitian terkait tentang efisiensi dengan metode yang sama juga dilakukan dengan Protokol Routing AOMDV Menggunakan Metode PA-SHORT di Jaringan MANET" [7]. Penemuan rute pada protokol routing AOMDV dilakukan dengan menghitung jarak berdasarkan jumlah hop. Jika jumlah hop meningkat, itu dapat menyebabkan penundaan yang cukup besar dan penurunan throughput. Penelitian ini membandingkan bagaimana kinerja protokol routing AOMDV dengan protokol routing Path AwareAOMDV (PA-AOMDV). Protokol routing PAAOMDV diperoleh melalui modifikasi kinerja protokol AOMDV dengan algoritma Path Aware SHORT. Algoritma Path Aware SHORT adalah metode untuk mengurangi jumlah hop. SHORT meningkatkan optimisasi rute dengan memantau rute dan mengoptimalkan rute ini yang memiliki jalur yang lebih baik. Kinerja kedua protokol akan dilihat sesuai denga empat metode pengukuran, yaitu throughput, averange end-to-end to delay, packet delivery ratio, dan routing overhead. Hasil menunjukkan bahwa throughput meningkat untuk 50 simpul adalah $61,84 \%$ dan untuk 100 simpul adalah $45,2 \%$, averange end-to-end to delay menurun untuk
50 simpul adalah $0,066 \%$ dan untuk 100 simpul $0,12 \%$, packet delivery ratio meningkat untuk 50 simpul adalah $60,87 \%$ dan untuk 100 simpul 82,02\%, dan routing overhead menurun untuk 50 simpul adalah 67,07\% dan 100 simpul 45,36\% [7].

g. Penetian terkait optimasi routing juga pernah dilakukan pada protokol routing MEDSR dengan metode Link Expiration Time (LET) untuk mendapatkan rute reliable yang dapat meningkatkan efisien energi. Penelitian ini memodifikasi route request kerangka protokol MEDSR untuk mengurangi pencarian rute baru. Hasil dari penelian ini menunjukkan bahwa protokol routing RMEDSR mampu mengoptimalkan pengunaan energi pada jaringan MANET dibandingkan tanpa menggunakan rute yang reliable [10].

\section{Metode Path Aware Short}

Bentuk jalur rute dapat berubah seiring dengan perubahan topologi akibat mobilitas simpul. Perubahan bentuk topologi ini dapat dimanfaatkan untuk mendapatkan jalur rute yang lebih baik jika dapat menghindari setiap overhead yang berlebihan.

Rute yang telah ditemukan dari simpul sumber A ke simpul tujuan I memiliki jalur A-B-C-D-E-F-G-H-I yang dijelaskan pada Gambar 1 (a). Rute awal ini ditentukan melalui proses penemuan rute, di mana jarak antara sumber dan tujuan adalah jarak terpendek menurut jumlah lompatan hop. Dibutuhkan 8 hop untuk pengiriman paket saat bergerak dari simpul A ke simpul I. Selama waktu tertentu, mobilitas simpul dapat membuat bentuk rute menjadi gambar yang ditunjukkan pada Gambar 1 (b). Selama waktu tertentu ini rute yang terbentuk mempertahankan konektivitas. Dalam bentuk baru ini, simpul J berada dalam transmisi simpul A dan simpul E berada dalam transmisi simpul J. Demikian pula simpul $\mathrm{H}$ berada dalam transmisi simpul F. Sehingga, idealnya rute terpendek dari simpul A ke simpul I hanya membutuhkan 5 hop seperti yang ditunjukkan pada Gambar 1 (c) [4] [7].

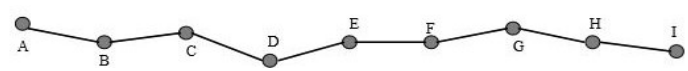

(a)

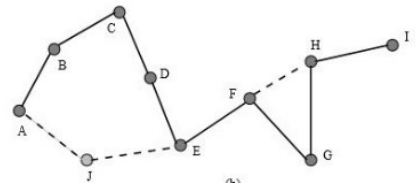

(b)

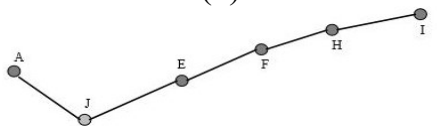

(c)

Gambar 1. Perubahan Jalur Rute [4]. 


\section{Jalannya Penelitian}

\section{A. Lingkungan Simulasi}

Lingkungan simulasi pada penelitian ini terdiri dari dua parameter, yaitu parameter pengukuran dan parameter skenario simulasi. Kedua parameter tersebut akan dijelaskan pada sub bab A.1. dan sub bab A.2.

\section{A.1. Parameter Pengukuran}

Beberapa parameter yang digunakan untuk menguji kinerja PA-SHORT ZRP terhadap ZRP yaitu:

1. Throughput : Kecepatan (rate) jumlah paket data yang akan diterima oleh simpul penerima setiap detiknya[11]. Throughput dihitung menggunakan persamaan 1 sebagai berikut.

Rumus:

$$
\text { Throughput (bps) }=\frac{\text { Ukuran data yang dikirim }}{\text { Waktu pengiriman data }}
$$

2. Average End-to-end delay: lama waktu jeda yang diperlukan pengiriman paket dari pengirim ke penerima paket. Average End-to-end delay dihitung menggunakan persamaan 2 sebagai berikut.

Rumus:

Rata-rata waktu jeda $(\mathrm{m} / \mathrm{s})=\frac{\text { Total waktu jeda }}{\text { Total paket yang diterima }}$

dimana,

Waktu Jeda $=$ Waktu Yang Diterima - Waktu Yang Dikirim

3. Packet delivery ratio (PDR): perbandingan antara paket data yang telah dikirimkan dengan jumlah paket data yang akan diterima. PDR dihitung dengan persamaan 3 sebagai berikut.

Rumus:

$$
\text { PDR }(\%)=\frac{\text { Paket data yang diterima }}{\text { Paket data yang dikirim }} \times 100 \%
$$

4. Routing overhead: jumlah paket routing yang akan dikirim oleh simpul sumber untuk mencapai simpul tujuan. Routing overhead dihitung menggunakan persamaan 4 sebagai berikut.

$$
\text { Routing Overhead }=\frac{\text { Jumlah paket } \text { routing }}{\text { Paket data yang diterima }}
$$

\section{A.2 Parameter Skenario Simulasi}

Pada tahap ini dilakukan penentuan perangkat keras maupun perangkat lunak yang digunakan dalam penelitian. Diantaranya adalah laptop, sistem operasi Linux Ubuntu, perangkat lunak network simulator 2 (NS2). Pada tahap ini juga dilakukan penentuan parameter uji coba penelitian yang dapat dilihat pada Tabel I.
TABEL I. Parameter Skenario.

\begin{tabular}{|c|c|}
\hline \multicolumn{2}{|c|}{ Parameter Skenario } \\
\hline Tipe Parameter & Nilai Parameter \\
\hline MAC layer & IEEE 802.11 \\
\hline Jumlah simpul & 20 simpul, 60 simpul, 100 simpul \\
\hline Network area & $500 \mathrm{~m} \times 500 \mathrm{~m}^{2}, 1000 \mathrm{~m} \times 1000 \mathrm{~m}^{2}$ \\
\hline Waktu simulasi & $200 \mathrm{~s}$ \\
\hline Kecepatan simpul & $1 \mathrm{~m} / \mathrm{s}, 5 \mathrm{~m} / \mathrm{s}, 10 \mathrm{~m} / \mathrm{s}$ \\
\hline Pause time & $45 \mathrm{~s}, 90 \mathrm{~s}, 180 \mathrm{~s}$ \\
\hline Pergerakan simpul & Random Waypoint \\
\hline Propagation & TwoRayGround \\
\hline Antena & Omni antenna \\
\hline Pola trafik & CBR \\
\hline
\end{tabular}

\section{B. Perancangan Skenario Penelitian}

Bagian perancangan skenario penelitian dibagi menjadi dua bagian yaitu, Merancang protokol dan merancang skenario simulasi

\section{B.1 Merancang protokol}

Pembuatan skrip PA-SHORT ZRP dilakukan dengan cara memodifikasi protokol routing ZRP dengan menyisipkan Algoritma PA-SHORT pada protokol ZRP. Penulisan kode dilakukan untuk menemukan jalur ShortCut. Jika ShortCut telah ditemukan maka jalur tersebut yang akan digunakan untuk melakukan pengiriman data.

\section{B.2 Merancang Skenario Simulasi}

Berikut merupakan diagram alir perancangan skenario simulasi yang dijelaskan pada Gambar 2.

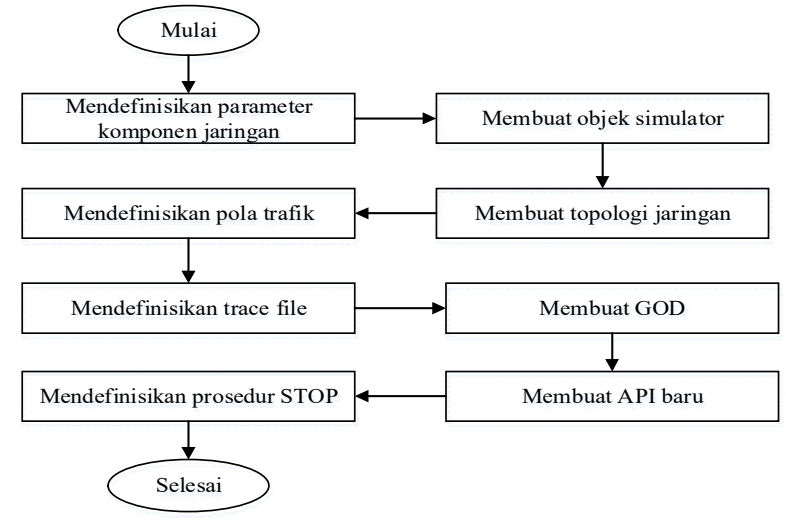

Gambar 2. Diagram Alir Pembuatan Skenario Simulasi

\section{Mekanisme Protokol Routing ZRP (Zone Routing Protocol)}

Pada Gambar 3 merupakan diagram alir penemuan jalur protokol routing ZRP 


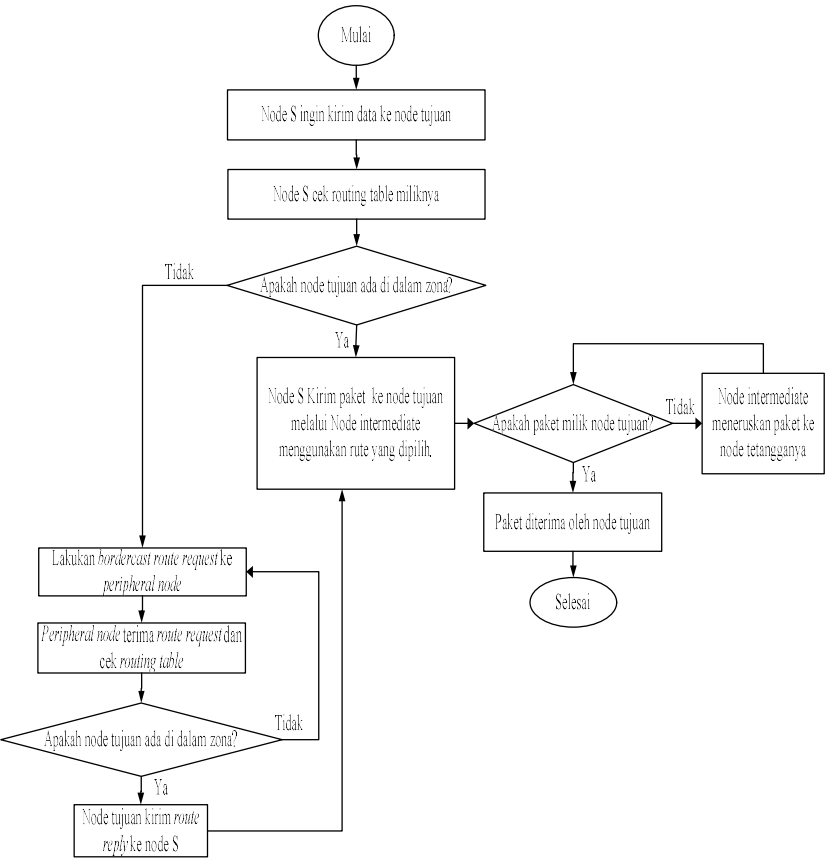

Gambar 3. Proses Penemuan Rute pada Protokol ZRP

Berdasarkan Gambar 3. dapat diketahui cara kerja ZRP sebagai berikut:

1. Pada saat simpul sumber memiliki paket untuk dikirim ke simpul tujuan. Simpul sumber menggunakan tabel routing yang disediakan oleh IARP untuk memastikan bahwa simpul tujuan berada dalam zonanya. Jika simpul tujuan ada di dalam zona maka paket data akan dikirim menggunakan jalur yang telah tersedia.

2. Jika simpul tujuan tidak ditemukan di dalam zona, maka akan dilakukan proses bordercast ke peripheral simpul, kemudian setiap peripheral simpul mencari simpul tujuan di dalam tabel routingnya. Proses akan terus diulangi hingga simpul tujuan ditemukan.

3. Ketika simpul tujuan telah ditemukan, maka akan dibuat route reply yang berisi jalur dari simpul tujuan ke simpul sumber dihasilkan dan dikirim kembali ke simpul sumber.

\section{Mekanisme PASHORT-ZRP}

Bentuk jalur rute dapat berubah secara signifikan saat konektivitas utuh karena mobilitas simpul. Perubahan bentuk dapat dimanfaatkan untuk mendapatkan jalur yang lebih baik jika dapat menghindari overhead yang signifikan. Pertimbangan jalur dari simpul S ke simpul D ditunjukkan pada Gambar 4 (a) dan jalur terpendek yang ditemukan adalah dari simpul S-E-I-L-T-U-D. Jalur awal ini ditentukan melalui proses penemuan jalur, di mana jarak antara simpul source (simpul S) dan destination simpul (simpul D) paling pendek dalam hal jumlah hop yaitu membutuhkan 6 hop. Mobilitas simpul dapat membuat bentuk jalur routing berubah sehingga mengakibatkan munculnya simpul Z mendekati simpul S yang ditunjukkan pada Gambar 4 (b). Dalam bentuk baru ini, simpul $\mathrm{S}$ berada pada rentang transmisi simpul $\mathrm{Z}$ sehingga simpul $\mathrm{S}$ masih dapat menjangkau simpul Z. Saat pengecekan, simpul $\mathrm{Z}$ masih dapat menjangkau simpul $\mathrm{T}$. Dengan demikian, jalur terpendek dari simpul S ke D hanya membutuhkan 4 hop seperti yang ditunjukkan Gambar 4 (c).

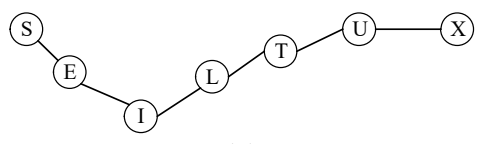

(a)<smiles>OC1OCOC1O</smiles>

(b)

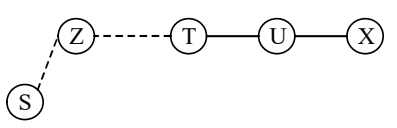

(c)

Gambar 4. Ilustrasi Path Aware SHORT.

Ketika paket dikirim oleh simpul tujuan, simpul tetangga akan mengecek apakah paket ditujukan untuk simpul tersebut atau tidak. Jika simpul tersebut merupakan simpul tujuan, maka paket langsung dikirimkan. Namun jika simpul tersebut bukan simpul tujuan, maka paket akan diteruskan ke simpul intermediate dan informasi Hop Count (HC) disimpan (HCi). Ketika paket lain datang untuk dikirim, paket akan dikirim melalui simpul intermediate $(\mathrm{HCj})$. Kemudian dilakukan perhitungan selisih nilai $\mathrm{HCi}$ dan $\mathrm{HCj}$, jika $\mathrm{HCi}$ dikurangi dengan $\mathrm{HCj}$ dan hasilnya lebih besar dari 2 , maka rute short-cut ditemukan. Namun, jika hasil kurang atau sama dengan 2, maka rute short-cut tidak ditemukan dan paket diteruskan ke simpul tetangga/selanjutnya. Setelah rute short-cut ditemukan, simpul akan mengirim pesan ke simpul sebelumnya untuk memperbarui tabel routing, pengiriman paket dikirimkan melalui rute short-cut [7].

Algoritma Path Aware Short mengoptimalkan rute berdasarkan hop terpendek, maka dari itu pada header tiap paket membawa bidang hop-count (HC). Bidang hopcount (HC) diinisialisasi ke nol pada simpul sumber dan bertambah setiap satu dari setiap hop yang dibutuhkan paket. Pada packet header terdapat informasi berupa alamat tujuan (DA), alamat sumber (SA), dan hop-count (HC). Terdapat NA, yaitu alamat tetangga dalam transmisi simpul yang menyiarkan paket. Format setiap entri adalah $<$ SA, DA, HC, NA $>$. Berikut adalah flowchart pencarian rute Algoritma Path Aware SHORT yang ditunjukkan oleh Gambar 5. 


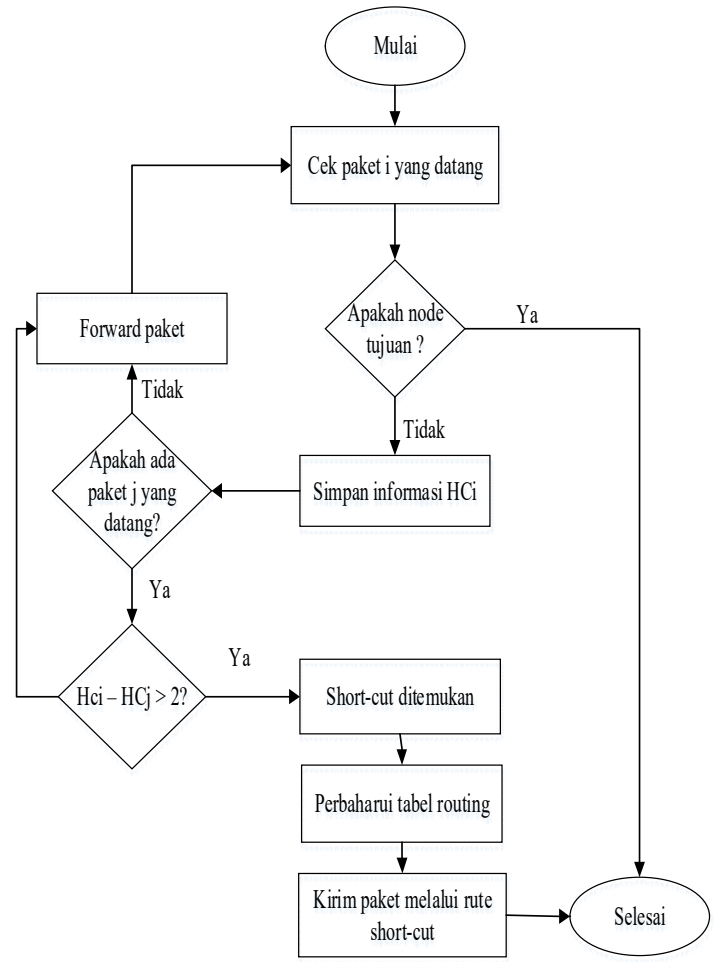

Gambar 5. Flowchart Path Aware-SHORT.

\section{HASIL DAN PEMBAHASAN}

\section{A. Analasis Parameter Uji Throughput}

Gambar 6-8 merupakan grafik rata-rata throughput sesuai hasil uji coba skenario.

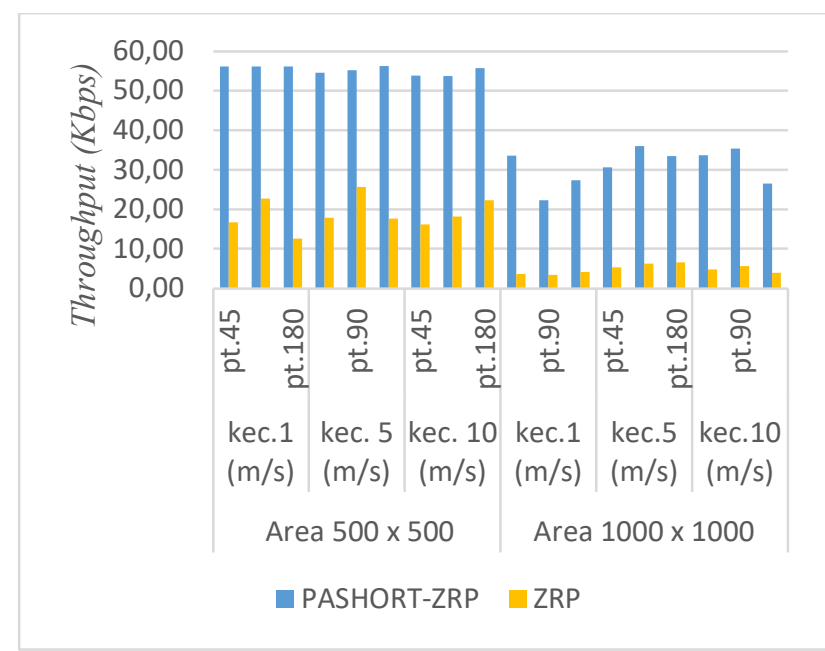

Gambar 6. Grafik Perbandingan Nilai Rata-rata Throughput Simpul 20 pada Area $500 \times 500 \mathrm{~m}^{2}$ dan $1000 \times 1000 \mathrm{~m}^{2}$

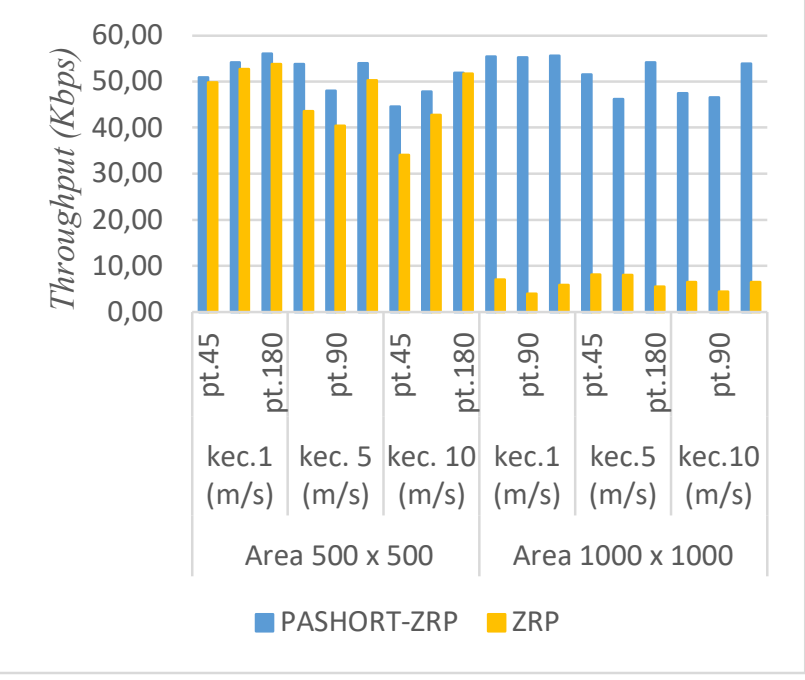

Gambar 7. Grafik Perbandingan Nilai Rata-rata Throughput Simpul 60 pada Area $500 \times 500 \mathrm{~m}^{2}$ dan $1000 \times 1000 \mathrm{~m}^{2}$

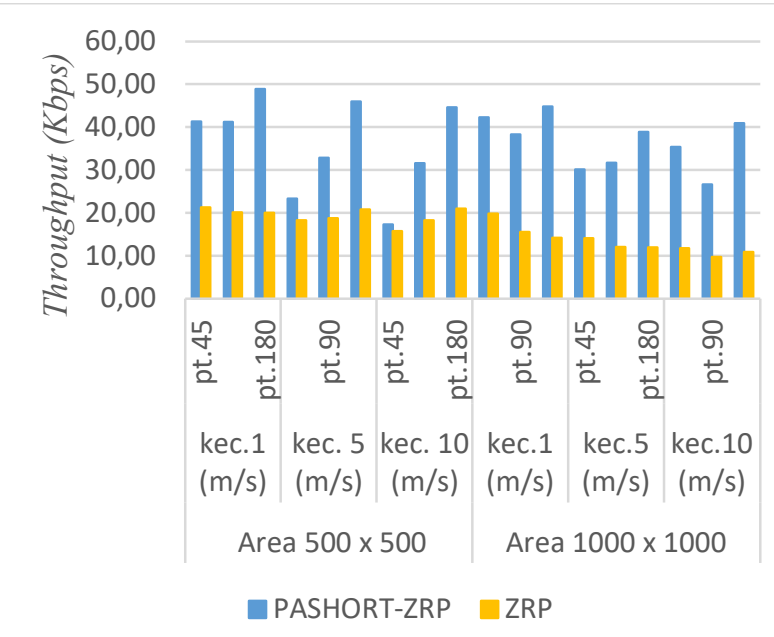

Gambar 8. Grafik Perbandingan Nilai Rata-rata Throughput Simpul 100 pada Area $500 \times 500 \mathrm{~m}^{2}$ dan $1000 \times 1000 \mathrm{~m}^{2}$

Hasil nilai troughput yang dihasilkan pada percobaan 1 sampai percobaan 5 terjadi perubahaan yang sangat signifikan pada percobaan luas area yang disediakan yaitu $1000 \times 1000 \mathrm{~m}^{2}$ untuk protokol ZRP. Hal ini disebabkan oleh adanya jarak antara simpul sumber dan simpul tujuan sangat jauh di luas area yang besar, sehingga membutuhkan banyak simpul yang tersedia di dalam jaringan maka zona routing semakin banyak terbentuk untuk dapat mengirimkan paket data. Karena setiap simpul memiliki informasi simpul tetangga pada zona lokalnya, maka apabila semakin banyak jumlah hop yang dilewati, sehingga semakin panjang rute yang diperoleh. Apabila semakin panjang rute yang dilewati, maka nilai troughput semakin menurun.

Perubahan kecepatan dan pause time juga mengakibatkan nilai troughput menurun, hal ini dapat terjadi adanya perubahan kecepatan sehingga mengakibatkan pergantian rute yang cukup sering. Ketika simpul sumber dan simpul tujuan saling bergerak 
berjauhan maka akan mengakibatkan semakin banyak rute yang terputus dan mengakibatkan proses pergantian rute semakin sering dilakukan. Pergantian rute tersebutlah yang menyebabkan banyak paket yang akan di drop dan membuat throughput mengalami penurunan.

Protokol PASHORT-ZRP mampu meningkatkan throughput pada ZRP, hal ini disebabkan oleh alogoritma PA-SHORT yang memperbaiki rute jika terdapat rute yang lebih panjang. Pada percobaan ini apabila semakin tinggi pause time, maka semakin lama waktu tiap simpul stabil sebelum pergerakan simpul berikutnya. Ini membutikan protokol routing PASHORT-ZRP lebih baik dari segi throughput jika dibandingkan dengan ZRP.

\section{B. Analasis Parameter Uji Packet Delivery Ratio}

Gambar 9-11 menunjukkan grafik rata-rata packet delivery ratio sesuai hasil uji coba skenario.

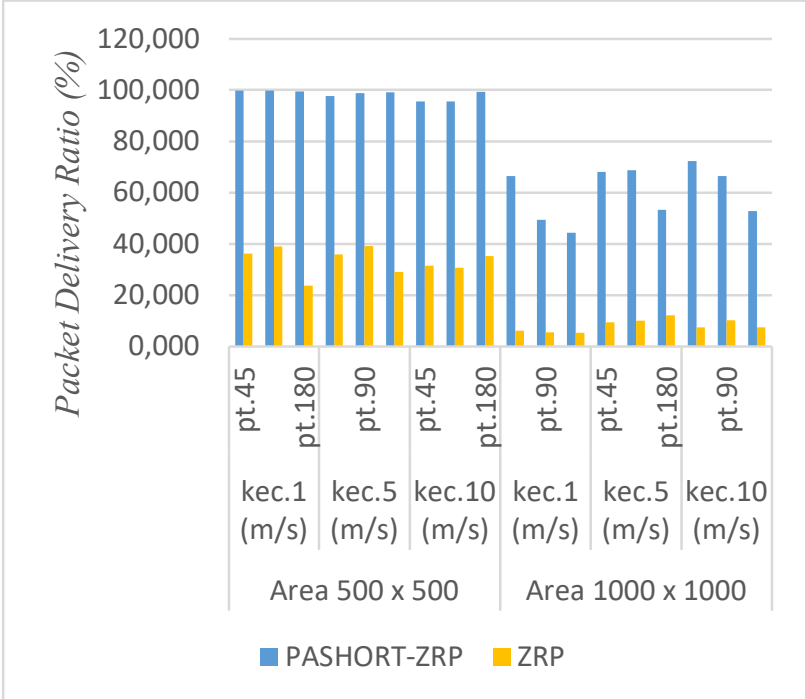

Gambar 9. Grafik Perbandingan Nilai Rata-rata Packet Delivery Ratio Simpul 20 pada Area $500 \times 500 \mathrm{~m}^{2}$ dan $1000 \times 1000 \mathrm{~m}^{2}$

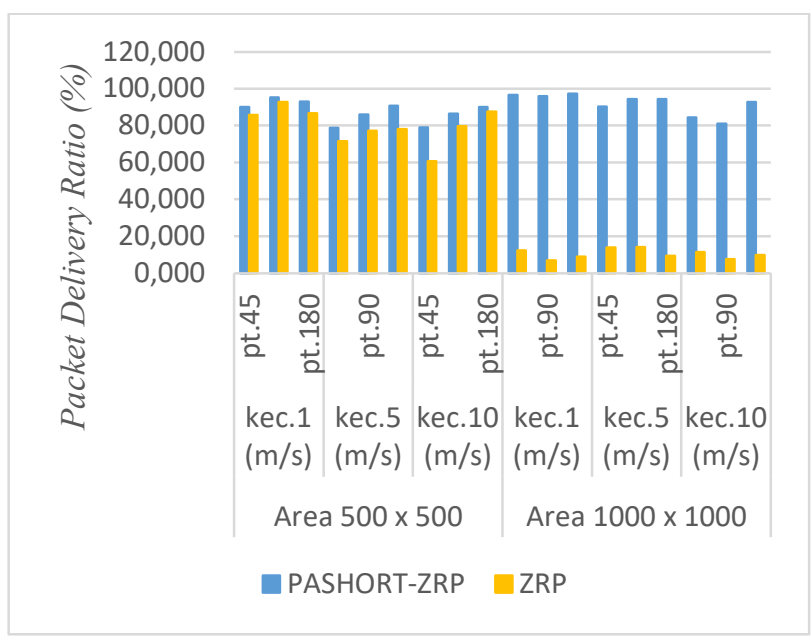

Gambar 10. Grafik Perbandingan Nilai Rata-rata Packet Delivery Ratio Simpul 60 pada Area $500 \times 500 \mathrm{~m}^{2}$ dan $1000 \times 1000 \mathrm{~m}^{2}$

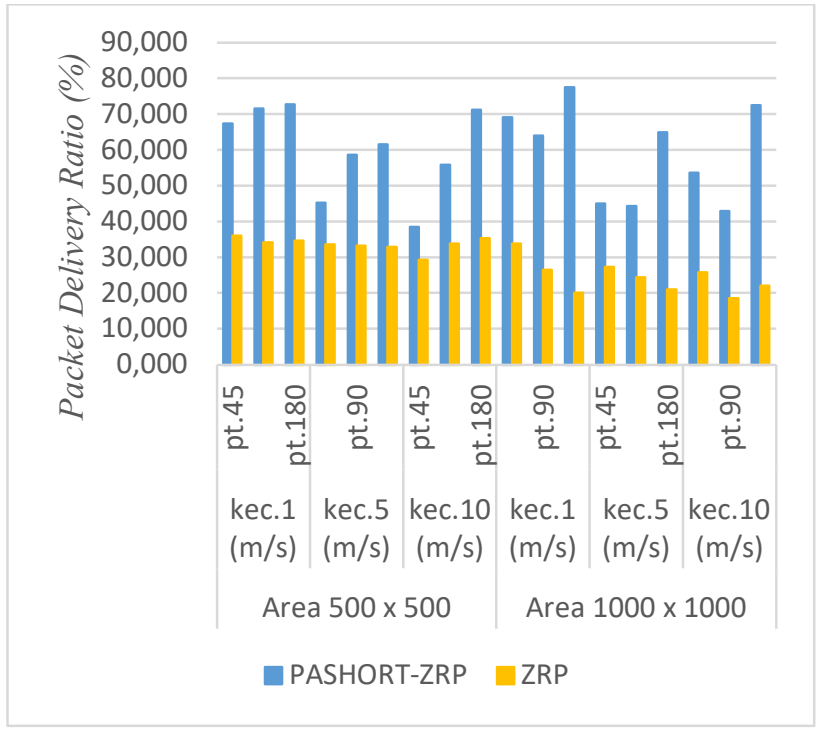

Gambar 11. Grafik Perbandingan Nilai Rata-rata Packet Delivery Ratio Simpul 100 pada Area $500 \times 500 \mathrm{~m}^{2}$ dan $1000 \times 1000 \mathrm{~m}^{2}$

Setelah dilakukan beberapa percobaan, protokol routing PASHORT-ZRP menghasilkan nilai rata-rata packet delivery ratio paling tinggi dari pada ZRP hal ini dikarenakan penerapan algoritma PA-SHORT pada protokol routing ZRP yang memperbaiki rute jika terdapat rute yang lebih panjang. Semakin tinggi kecepatan simpul, menyebabkan simpul akan semakin cepat bergerak, semakin cepat simpul bergerak maka rute yang akan dilalui untuk mengirimkan paket juga akan semakin cepat berubah karena rute mengalami putus link. Sehingga banyak paket yang akan di drop karena simpul pengirim paket selanjutnya tidak ditemukan dan menyebabkan protokol harus mencai rute baru.

Pada protokol routing ZRP maupun PASHORT-ZRP pause time juga mempengaruhi pegerakan simpul, semakin sering simpul bergerak, maka zona yang terbentuk akan semakin sering berubah dan semakin banyak jumlah hop yang dihasilkan, hal tersebut menyebabkan proses penemuan rute semakin sering dilakukan. Serta, hal ini menyebabkan semakin tingginya buffer paket data pada jaringan.

\section{Analisis Parameter Uji Rerata End-to-end Delay}

Gambar 12-14 merupakan grafik rata-rata rerata endto-end delay sesuai hasil uji coba skenario. 


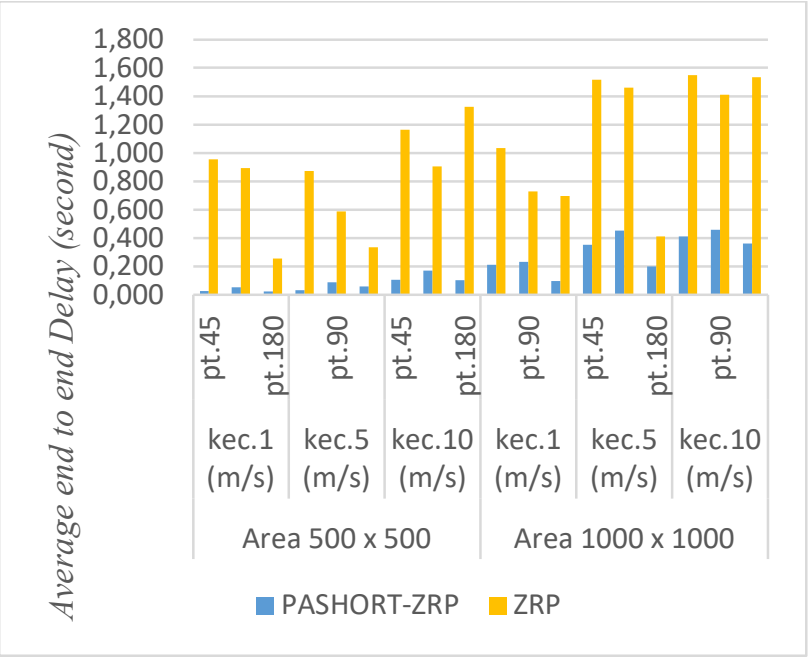

Gambar 12. Grafik Perbandingan Nilai Rata-rata Average End-to-end Delay Simpul 20 pada Area $500 \times 500 \mathrm{~m}^{2}$ dan $1000 \times 1000 \mathrm{~m}^{2}$

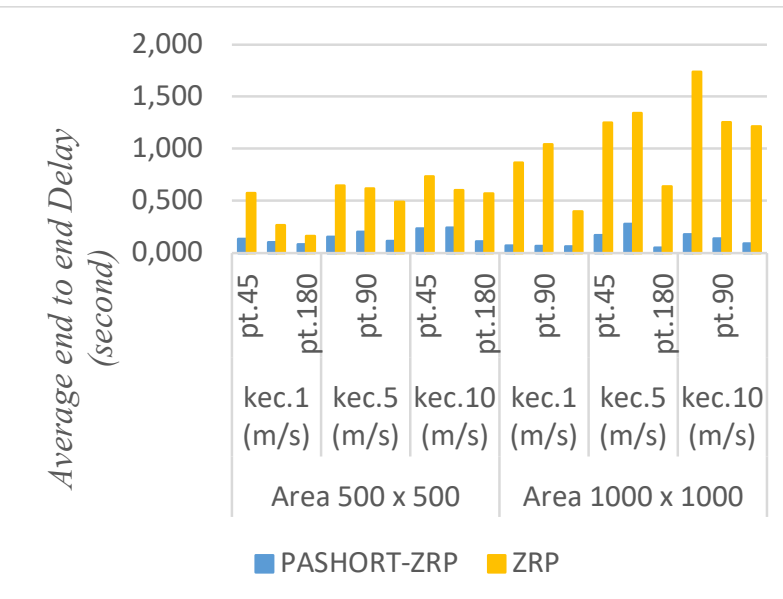

Gambar 13. Grafik Perbandingan Nilai Rata-rata Average End-to-end Delay Simpul 60 pada Area $500 \times 500 \mathrm{~m}^{2}$ dan $1000 \times 1000 \mathrm{~m}^{2}$

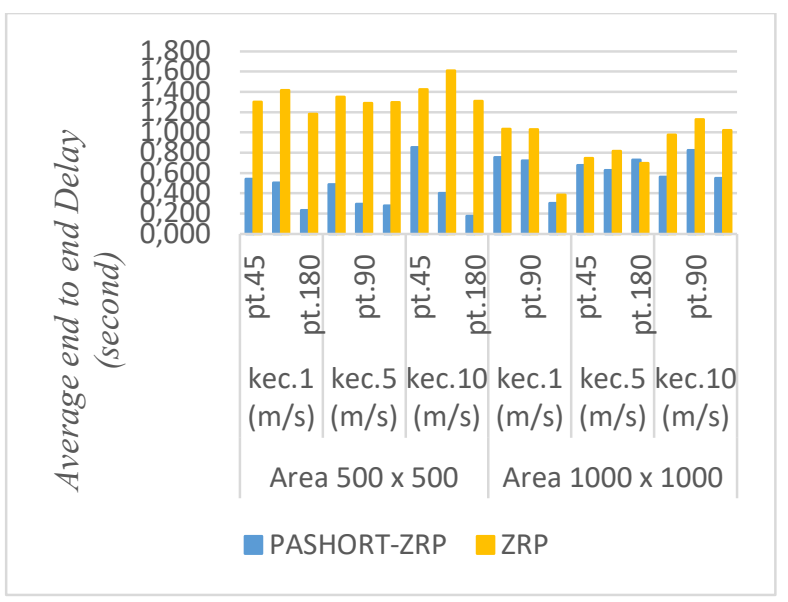

Gambar 14. Grafik Perbandingan Nilai Rata-rata Average End-to-end Delay Simpul 100 pada Area $500 \times 500 \mathrm{~m}^{2}$ dan $1000 \times 1000 \mathrm{~m}^{2}$

Hasil nilai rata-rata average end-to-end delay yang dihasilkan pada percobaan 1 samapai 5 memperlihatkan bahwa protokol routing ZRP memiliki nilai waktu jeda (delay) yang lebih tinggi, hal ini dikarenakan jika simpul tujuan tidak berada dalam zona sumber, maka, IERP akan melakukan bordercast untuk menemukan rute yang menyebabkan adanya delay tambahan. Delay akan terus meningkat ketika jarak antara simpul sumber dan tujuan semakin jauh, karena semakin sering bordercast yang dilakukan membuat semakin banyak simpul berkomunikasi di zona yang sama menyebabkan delay ZRP semakin rendah, hal ini dikarenakan adanya pemeliharaan informasi routing yang dilakukan oleh IARP.

Adanya penerapan algoritma PA-SHORT pada protokol routing ZRP terbukti dapat menurunkan nilai delay. Hal ini dikarenakan algoritma PA-SHORT meningkatkan optimasi routing yang secara bertahap memperpendek rute bila memungkingkan. Adanya peningkatan kecepatan simpul, menyebabkan semakin sering dilakukan pencarian rute akibat rute sebelumnya terputus, sehingga semakin sering pencarian rute dilakukan maka semakin tinggi delay pengiriman paket pada routokol. Pada protokol routing ZRP maupun PASHORT-ZRP semakin sering simpul bergerak, maka zona yang terbentuk akan semakin sering berubah dan semakin banyak jumlah hop yang dihasilkan, hal tersebut menyebabkan proses penemuan rute semakin sering dilakukan. Serta, hal ini menyebabkan semakin tingginya buffer paket data pada jaringan.

\section{Analasis Parameter Uji Routing Overhead}

Gambar 15-17 merupakan grafik rata-rata routing overhead sesuai hasil uji coba skenario.

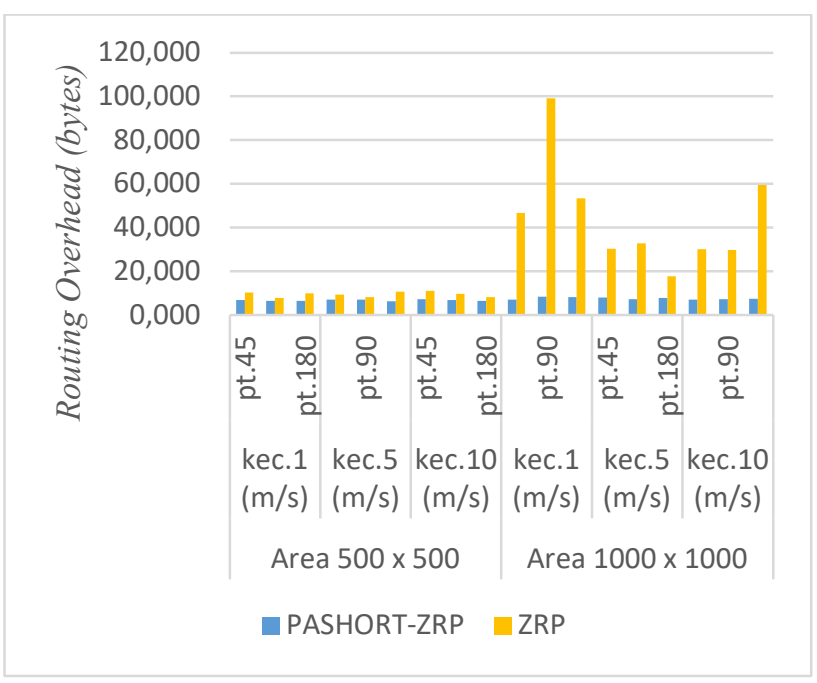

Gambar 15. Grafik Perbandingan Nilai Rata-rata Routing Overhead Simpul 20 pada Area $500 \times 500 \mathrm{~m}^{2}$ dan $1000 \times 1000 \mathrm{~m}^{2}$ 


\section{0,000}

160,000

140,000

120,000

100,000

80,000

60,000

20,000

on

竝

0,000
40,000

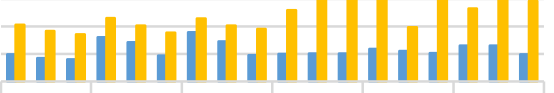

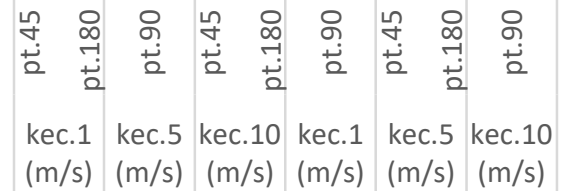

Area $500 \times 500 \quad$ Area $1000 \times 1000$

$\square$ PASHORT-ZRP $\square$ ZRP

Gambar 16. Grafik Perbandingan Nilai Rata-rata Routing Overhead Simpul 60 pada Area $500 \times 500 \mathrm{~m}^{2}$ dan $1000 \times 1000 \mathrm{~m}^{2}$

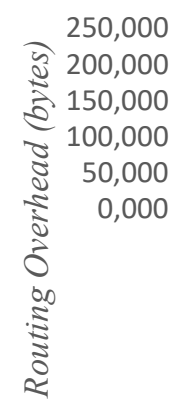

Nilai routing overhead yang dihasilkan protokol routing PASHORT-ZRP menghasilkan nilai yang lebih kecil dengan protokol routing ZRP, karena penerapan algoritma PA-SHORT meningkatkan optimasi routing secara bertahap memperpendek rute apabila memungkinkan. Semakin pendek rute, maka semakin rendah nilai routing overhead. hal ini membuktikan bahwa protokol routing PASHORT-ZRP lebih baik dari segi routing overhead jika dibandingkan dengan ZRP.

\section{KESIMPULAN DAN SARAN}

\section{A. Kesimpulan}

Setelah melakukan simulasi dan analisa terhadap kedua algoritma protokol routing PASHORT-ZRP dan ZRP maka dapat ditarik beberapa kesimpulan yaitu:

1. Dari hasil simulasi, optimasi protokol routing dengan menggunakan algoritma PA-SHORT meningkatkan kinerja dalam hal throughput. Hasil throughput pada PASHORT-ZRP mengalami peningkatan sebesar $36.45 \%$ untuk simpul 20, 3.21 $\%$ untuk simpul 60 , dan $16.97 \%$ untuk simpul 100 di daerah $500 \times 500 \mathrm{~m}^{2}$. Sedangkan pada daerah 1000 $\times 1000 \mathrm{~m}^{2}$ hasil throughput PASHORT-ZRP mengalami kenaikan sebesar $26.16 \%$ untuk simpul $20,45.59 \%$ untuk simpul 60 , dan $23.2 \%$ untuk simpul 100 .

2. Hasil packet delivery ratio pada PASHORT-ZRP mengami peningkatan sebesar $64.931 \%$ untuk simpul 20,7.763\% untuk simpul 60 , dan $26.644 \%$ untuk simpul 100 di daerah $500 \times 500 \mathrm{~m}^{2}$. Sedangkan pada daerah $1000 \times 1000 \mathrm{~m}^{2}$ hasil packet delivery ratio PASHORT-ZRP mengalami kenaikan sebesar $52.081 \%$ untuk simpul 20,81.475\% untuk simpul 60, dan $34.912 \%$ untuk simpul 100 .

Gambar 17. Grafik Perbandingan Nilai Rata-rata Routing Overhead Simpul 100 pada Area $500 \times 500 \mathrm{~m}^{2}$ dan $1000 \times 1000 \mathrm{~m}^{2}$

Pada Gambar 15-17 terlihat bahwa hasil rata-rata nilai outing overhead tidak selalu stabil, hal ini dikarenakan oleh kemungkinan jarak yang timbul antara simpul pengirim dan simpul penerima yang berada saling berjauhan sehingga membutuhkan banyak simpul yang tersedia di dalam jaringan maka zona routing akan semakin banyak terbentuk untuk dapat mengirimkan paket data. Karena setiap simpul memiliki informasi simpul tetangga pada zona lokalnya, maka semakin banyak julah hop yang dilewati, sehingga semakin panjang rute yang diperoleh. Apabila semakin panjang rute yang dilewati, maka nilai routing overhead semakin tinggi.

Perubahan kecepatan dan pause time juga mengakibatkan nilai routing overhead menurun, hal ini dapat terjadi adanya pause time sehingga mengakibatkan pergantian rute yang cukup sering. Ketika simpul sumber dan simpul tujuan saling bergerak berjauhan maka akan mengakibatkan semakin banyak rute yang terputus dan mengakibatkan proses pergantian rute semakin sering dilakukan. Pergantian rute tersebutlah yang menyebabkan banyak paket yang akan di drop dan membuat routing overhead mengalami peningkatan

3. Hasil average end-to-end delay pada PASHORTZRP mendapatkan nilai yang lebih kecil dibanding sebelumnya yaitu $0.737 \%$ untuk simpul $20,0.365 \%$ untuk simpul 60, dan $0.939 \%$ untuk simpul 100 di daerah $500 \times 500 \mathrm{~m}^{2}$. Sedangkan pada daerah 1000 $\times 1000 \mathrm{~m}^{2}$ hasil average end-to-end delay PASHORT-ZRP mengalami penurunan sebesar $0.841 \%$ untuk simpul $20,0.960 \%$ untuk simpul 60 , dan $0.232 \%$ untuk simpul 100 .

4. Hasil routing overhead pada PASHORT-ZRP mengami penurunan sebesar $2.664 \%$ untuk simpul $20,15.872 \%$ untuk simpul 60 , dan $83.201 \%$ untuk simpul 100 di daerah $500 \times 500 \mathrm{~m}^{2}$. Sedangkan pada daerah $1000 \times 1000 \mathrm{~m}^{2}$ hasil routing overhead PASHORT-ZRP mengalami penurunan sebesar $36.815 \%$ untuk simpul 20, $56.267 \%$ untuk simpul 60, dan $37.538 \%$ untuk simpul 100.

5. Dengan menerapkan algoritma Path Aware SHORT dapat meningkatkan kinerja protokol routing ZRP dalam memanfaatkan perubahan topologi jaringan dengan cara mengurangi jumlah hop pada rute utama agar rute menjadi lebih optimal. 


\section{B. Saran}

Berdasarkan kesimpulan yang telah diberikan dari penelitian di atas, maka saran - saran yang perlu diperhatikan adalah sebagai berikut:

1. Melakukan penelitian menggunakan protokol routing mesh/tree pada jaringan MANET dengan penerapan algoritma Path Aware SHORT.

2. Melakukan penelitian terkait dengan menggunakan protokol routing yang sama dengan parameter simulasi yang berbeda dengan menggunakan jumlah simpul lebih banyak dan pause time lebih variasi.

3. Melakukan penelitian terkait dengan menggunakan protokol routing yang sama dengan algoritma Energy Aware SHORT.

\section{DAFTAR PUSTAKa}

[1] A. A. Haqqi, Ma'ruf Nashrul, Sukiswo, Zahra, "Analisis Kinerja Puma Pada Manet Menggunakan Ns 2," Transient, vol. 2, no. 3, pp. 765-769, 2013.

[2] S. Hud, R. Primananda, and S. R. Akbar, "Analisis Perbandingan Performa Routing Flooding dan Convergecast Pada Wireless Sensor Network," $J$. Pengemb. Teknol. Inf. dan Ilmu Komput. Univ. Brawijaya, vol. 1, no. 3, pp. 166-173, 2017.

[3] J. Anthoni and V. W. Mahyastuty, "Evaluasi Kinerja Zone Routing Protocol Pada Mobile Ad-Hoc Network," J. Elektro, vol. 7, no. 1, pp. 1-14, 2014.

[4] C. Gui and P. Mohapatra, "SHORT: Self-Healing and Optimizing Routing Techniques for Mobile Ad Hoc Networks," ACM Int. Symp. Mob. Ad Hoc Netw. Comput., pp. 279-290, 2003.
[5] R. Asokan, A. M. Natarajan, and C. Venkatesh, "Quality-of-Service Routing Using Path and Power Aware Techniques in Mobile Ad Hoc Networks," $J$. Comput. Syst. Networks, Commun., vol. 2008, pp. 17, 2008.

[6] N. Fahriani, S. Djanali, and A. M. Shiddiqi, "EFISIENSI RUTE PADA PROTOKOL DSR MENGGUNAKAN PA-SHORT," pp. 1-8, 2012.

[7] Y. P. Wulandari, A. H. Jatmika, and F. Bimantoro, "MENINGKATKAN EFISIENSI RUTE PADA PROTOKOL ROUTING AOMDV MENGGUNAKAN METODE PA-SHORT ( Improving Route Efficiency on the AOMDV Routing Protocol Using PA-SHORT on the Mobile Ad-Hoc Network )."

[8] B. S. Kusuma, D. Risqiwati, and D. R. Akbi, "Analisis Perbandingan Performansi Protokol Ad Hoc On- Demand Distance Vector dan Zone Routing Protocol Pada Mobile Ad Hoc Network," Kinet. UMM, vol. 2, no. 3, pp. 165-174, 2017.

[9] S. A. Sasongko and A. A. Zahra, "Analisis Performansi Dan Simulasi Protokol Zrp ( Zone Routing Protocol ) Pada Manet ( Mobile Ad Hoc Network ) Dengan Menggunakan Ns-2,” pp. 1-8, 2010.

[10] M. H. Andy Hidayat Jatmika, Supeno Djali, "Optimasi Routing pada Jaringan MANET Menggunakan MEDSR dan LET,” Pros. Semin. Nas. Manaj. Teknol. XIII, 2011.

[11] H. Akbar, A. H. Jatmika, and M. A. Albar, "Analisis Pengaruh Metode LET Pada Protokol Routing DSDV Untuk Efisiensi Pencarian Rute Pada Jaringan MANET," pp. 1-7. 